\title{
The effect of 8 week resistance exercise on some anthropometric measurements and body composition to Sedentary Women
}

\author{
Turğut M. ${ }^{\mathrm{ABCDC}}$, Bağir S. ${ }^{1 \mathrm{ABCDE}}$, Sarikaya M. ${ }^{2 \mathrm{ABCDE}}$, Tinaz Ü. ${ }^{3 \mathrm{ABCDE}}$ \\ ${ }^{\prime}$ Sakarya University of Applied Sciences, Faculty of Sport Sciences, Sakarya, Turkey \\ ${ }^{2}$ Van Yüzüncü Yll University, Physical Education and Sports Academy, Van, Turkey \\ ${ }^{3}$ Bartin University, Physical Education and Sports Academy, Bartın, Turkey
}

Authors' Contribution: A - Study design; B - Data collection; C - Statistical analysis; D - Manuscript Preparation; E - Funds Collection.

\begin{abstract}
Purpose: $\quad$ The aim of this study is to determine the effect of resistance exercise program applied to eight weeks on some anthropometric measurements and body composition in sedentary women.

Material: $\quad$ Fifteen volunteer women with a mean age of $20.67 \pm 1.29$ years were included in the study. After asking the participants whether there are any health problems before the exercise program, detailed information was given and the exercises were implemented correctly and efficiently. Participants were given a 45-minute resistance exercise for 3 days a week. In order to compare the data obtained (Wilcoxon Test) was applied to compare descriptive statistics with pre- and post-exercise values via using SPSS 22.0. Before and after the exercise program (Weight, Hip circumference, calf circumference, chest circumference, waist circumference, shoulder circumference and BMI) were measured.

Results: $\quad$ According to the findings of the study, it was determined that there was a significant difference between the anthropometric measurement and body composition values of the exercise program applied before and after the exercise program of the participating women $(p>0.05)$.

Conclusions: In conclusion, the effects of regularly performed exercises, especially aerobic and resistance exercises done for women, on persons are seen in the literature and research essays. Deterioration in the body composition of women is seen depending on age and excessive weight.

Keywords: Sedentary Women, weight, BMI, fat and obesity
\end{abstract}

\section{Introduction}

Today, it preserves its reality that unhealthy nutrition culture, being far from bodily movement and the sedentary living approach, as a result of these, are introduced by technological developments. Sedentary life increases the emergence probability of cardiovascular diseases, deformation in the joints, backbone disorders, depression, and many more diseases. These negative results made that it is mandatory that individuals tend to exercise for maintaining body and spiritual health [1].

Exercise is effective for burning the fats in our bodies with respect to provide energy and prevents excessive loss in the muscle tissue during weight workout [2]. It is required to continue the exercise program for at least 8 weeks in order to ensure loss in the fatty tissue. It should be continued lifelong to become the life standard [3].

Exercise is considered as one of the basic principles of healthy life. A healthy life with exercise can only be possible if the exercise programs are done according to the purpose [4]. Regular exercise is very important for a healthy, active aging. In the advanced ages, physical capacity is closer to the threshold value and even minimal decreases negatively affect daily activities such as getting out of the chair. An added disease attack may make an elder, who was healthy beforehand, dependent and immobile. The way to prevent such unwanted incidents is the regular physical exercises. Even in the very advanced ages, the physical capacity may be increased via regular physical activity [5]. One of the exercise types used for (c) Turğut M., Bağir S., Sarikaya M., Tinaz Ü., 2019 doi:10.15561/20755279.2019.0207 burning fats and increasing muscle mass and preferred intensely by large masses is resistance exercises (RE).

Resistance exercise (RE) workout is a special workout method, consisting of exercises designed for increasing the muscle power, muscle strength and muscle force. When resistance exercise workout is mentioned, mainly strength workout or weight workout are thought of. Together with this being correct, strength workout consists of only a form of RE workouts: anything that ensures that muscle works more or harder can be classified as RE workout. Stretching made by using surgical pipes, elastic band workouts and the workouts made by throwing medicine ball are also described as RE workout [6].

The improvements in the muscle force and strength as a result of a resistance workout is smaller for women compared with the one observed in men. The resistance workout causes big increases in the body composition and muscle size especially for women [7].

Even though there are similarities in the body composition, organs and members in the body, every person has a physical composition different from each other. Body composition refers different tissues, expressed as generally muscle, fatty, bone, and residual masses, forming the total body mass. However, in the physical fitness tests, the body composition is usually assessed as the fatty tissue and the body tissue, separated from fat [8]. Waist girth is an indicator of the deep fatty tissue. When compared to the top leg and hip girth, it is used as an indicator of the fatty tissue and muscle distribution level. Higher the ratio of the waist girth to the top leg and hip 
girth, higher the diabetes risk. On the other hand, waist girth has a high correlation with the weight/length ${ }^{2}$, which is an indicator for fatness [9]. In the studies performed, it is shown that body fat amount, increased with the age, can be decreased by increasing physical activity [10].

It was thought that there may be positive changes which may be created by resistance exercises in the sedentary women's some anthropometric measurements and body compositions. For this purpose, in this study, the effect of 8 week resistance exercises on some anthropometric measurements and body composition.

\section{Material and Methods}

Participants

Fifteen volunteer women with a mean age of $20.67 \pm$ 1.29 years were included in the study.

Research Design

After asking the participants whether there are any health problems before the exercise program, detailed information was given and the exercises were implemented correctly and efficiently. Participants were given a 45-minute resistance exercise for 3 days a week.

The pre-final test model was used in the research. For this purpose, length, weight, body mass index (BMI), diameter and girth measurements were taken from sedentary women just before and just after the workout program lasted for 8 weeks.

Length and weight measurement

The measurement of the tallness lengths of the athletes, participating in the study, was done while the head is in the Frankfort plane, with bare feet, posture is in a perpendicular position and from the vertex of the head during a deep inhaling and the assessment was recorded in $\mathrm{cm}(0.1 \mathrm{~cm})$. The body weight measurements were taken with bare feet in $\mathrm{g}(0.01 \mathrm{~g})$ when there are only shorts on the participants.

\section{Diameter measurements}

Chest girth: the measurement was done at the level of rib 5 and 6 (at the level of nipple of men) while the arms are slightly open to the sides [11].

Hip girth: the measurement points were determined after the pressure applied to the soft tissue by approaching the tool from the sides while the subject is standing up, slightly opened the arms to the sides. It was measured by placing the big caliper on the iliocristale points (of femora) [12].

Shoulder girth: it was measured from the most obvious parts of the shoulder bones such that caliper with curved edge comes parallel to the ground while the subject is in the anatomic position [13].

Circumference measurements

Waist girth: measurement of the waist girth was measured in the narrowest part of the waist and recorded in $\mathrm{cm}$ while the subjects, with thin and light clothes, are standing up, the waist is in loose position, arms are hanged on the sides, the legs are close [14].

Hip girth: was measured at the symphysis pubis level from the front and maximal protrusion of the hip muscles from the behind [15].
Chest girth: the chest girth measurements was measured as breathed half out by placing the measurement band, when the arms are opened to the sides, $2.5 \mathrm{~cm}$ over the nipples, in the position with legs opened to the shoulder width, while the breast body is at perpendicular position and lowering the arms and recorded as $\mathrm{cm}$ [11].

Body mass index (BMI)

The body composition can be referred as the combination of body fat mass and lean body mass [16]. In our study, in order to find out the body fat percentage measurements of the participants, we assessed with the device in the TANITA model, depending on the individuals' BIA basic conditions.

Exercise and Workout Program: The training program, which lasted 8 weeks, consisted of 60 minutes of resistance exercises program, 3 days a week. After 10 minutes of warm-up in each exercise period, the exercises in Table 1 were applied. The applied program was completed with 5 minutes cooling exercises.

Table 1. Types of exercise, duration and shape

\begin{tabular}{|c|c|}
\hline Exercises & Period \\
\hline Push up with exercise band & $2 * 12$ sets \\
\hline $\begin{array}{l}\text { Shoulder movements with exercise } \\
\text { band }\end{array}$ & $2 * 12$ sets \\
\hline Squat with exercise band & $2 * 12$ sets \\
\hline Thrust movement with exercise band & $2 * 12$ sets \\
\hline Stand out squat with exercise band & $2 * 12$ sets \\
\hline Penguin movement with exercise band & $2 * 12$ sets \\
\hline $\begin{array}{l}\text { Baseball swing movement with exercise } \\
\text { band }\end{array}$ & $2 * 12$ sets \\
\hline
\end{tabular}

\section{Statistical analysis}

SPSS 22.0 package software was used in the analysis of the data obtained. In order to determine the differences between the pre-test and final test values of the study group, Wilcoxon test, one of the non-parametric tests, was used.

\section{Results}

Table 2. Age and tall statures of the sedentary women participating in the research

\begin{tabular}{llll}
\hline Indicators & N & Average & St. deviation \\
\hline Age (year) & 15 & 20.67 & 1.29 \\
Tall stature $(\mathrm{cm})$ & 15 & 159.47 & 4.80 \\
\hline
\end{tabular}

Considering the physical characteristics of the women, participating in the research, in the Table 1, the age, length and body weight were determined respectively as: $20.67 \pm 1.29$ years, $159.47 \pm 4.80 \mathrm{~cm}$.

According to the findings obtained, it was determined that the exercise program applied affected positively some anthropometric measurement results compared to the pre-test results and this effect is statistically significant $(\mathrm{p}>0.05)$. 
Assessing the results of the research, it was determined that the exercise program applied significantly changed the body composition in sedentary women compared with the pre-test results and this changes is statistically significant $(\mathrm{p}>0.05)$.

\section{Discussion}

The effect of the regular exercise on the cardiovascular risk factors, diabetes, dyslipidemia, and hypertension treatment is well-known [17]. In addition to all these diseases, together with the sedentary life, there are obesity, disorders with respect to aesthetics, and psychological disorders occurring as a result of these. It is seen that the exercise programs applied in a planned way are an efficient way used for correcting the energy balance deteriorated in the treatment of diseases linked with obesity, emerged, and excessive weights.

In our research, it was done in order to determine the effect of the 8 week resistance exercise program on the body compositions and some anthropometric measurements of women. Following the preliminary test and 8 week resistance exercise program, done, of the sedentary women, a significant difference was found in favor of final tests between the final test VA, BKI, fat percentage and some circumference measurement tests $(\mathrm{p}<0.05)$.

Erbas [18] researched the effect of regular, aerobic exercise protocol for 6 months on 54 middle aged, sedentary women. He applied 3 tests as the preliminary test before the workout, the interim test after 3 months and final test after 6 months. After the exercise protocol made, it was found out that the interim test is meaningful compared with the preliminary test, the final test with both the preliminary and intermediary test between the preliminary test, intermediary test and final test values of SKB, DKB, VA, VYO, BKI, and EKK measurements of

Table 3. Comparison on some circumference measurement values of the women

\begin{tabular}{|c|c|c|c|c|c|c|}
\hline Measurements (cm) & Sequences & $\mathbf{N}$ & $\begin{array}{l}\text { Sequence } \\
\text { average }\end{array}$ & Sequence total & $\mathbf{Z}$ & $\mathbf{p}$ \\
\hline \multirow[t]{3}{*}{ Weight pre-test - final test } & Negative sequences & $14^{b}$ & 7.96 & 111.50 & \multirow{3}{*}{$-2.92 * *$} & \multirow{3}{*}{.003} \\
\hline & Positive sequences & 1 & \multirow{2}{*}{8.50} & \multirow{2}{*}{8.50} & & \\
\hline & Equal & - & & & & \\
\hline Hip girth pre-test - & Negative sequences & $12^{\mathrm{b}}$ & 6.50 & 78.00 & \multirow{3}{*}{$-3.12 * *$} & \multirow{3}{*}{.002} \\
\hline \multirow[t]{2}{*}{ Final test } & Positive sequences & 0 & \multirow[t]{2}{*}{.00} & \multirow[t]{2}{*}{.00} & & \\
\hline & Equal & 3 & & & & \\
\hline Calf girth pre-test - & Negative sequences & $14^{\mathrm{b}}$ & 7.50 & 105.00 & \multirow{3}{*}{$-3.34 * *$} & \multirow{3}{*}{.001} \\
\hline \multirow[t]{2}{*}{ Final test } & Positive sequences & 0 & \multirow[t]{2}{*}{.00} & \multirow[t]{2}{*}{.00} & & \\
\hline & Equal & 1 & & & & \\
\hline \multirow{3}{*}{$\begin{array}{l}\text { Chest girth pre-test } \\
\text { - Final test }\end{array}$} & Negative sequences & $15^{\mathrm{b}}$ & \multirow{3}{*}{$\begin{array}{l}8.00 \\
.00\end{array}$} & \multirow{3}{*}{$\begin{array}{l}120.00 \\
.00\end{array}$} & \multirow{3}{*}{$-3.41^{* *}$} & \multirow{3}{*}{.001} \\
\hline & Positive sequences & 0 & & & & \\
\hline & Equal & 0 & & & & \\
\hline \multirow{3}{*}{$\begin{array}{l}\text { Waist girth pre-test } \\
\text { - Final test }\end{array}$} & Negative sequences & $14^{\mathrm{b}}$ & \multirow{3}{*}{$\begin{array}{l}8.36 \\
3.00\end{array}$} & \multirow{2}{*}{117.00} & \multirow{3}{*}{$-3.24 * *$} & \multirow{3}{*}{.001} \\
\hline & Positive sequences & 1 & & & & \\
\hline & Equal & 0 & & 3.00 & & \\
\hline \multirow{3}{*}{$\begin{array}{l}\text { Shoulder girth pre-test } \\
\text { - Final test }\end{array}$} & Negative sequences & $13^{b}$ & \multirow{3}{*}{$\begin{array}{l}7.00 \\
.00\end{array}$} & \multirow{3}{*}{$\begin{array}{l}91.00 \\
.00\end{array}$} & \multirow{3}{*}{$-3.27^{* *}$} & \multirow{3}{*}{.001} \\
\hline & Positive sequences & 0 & & & & \\
\hline & Equal & 2 & & & & \\
\hline
\end{tabular}

$* * p<0.01$

Table 4. Wilcoxon test results in the BMI and fat percentage parameters of the women

\begin{tabular}{|c|c|c|c|c|c|c|}
\hline Measurements $(\mathrm{cm})$ & Sequences & $\mathbf{N}$ & $\begin{array}{l}\text { Sequence } \\
\text { average }\end{array}$ & Sequence total & $\mathbf{Z}$ & p \\
\hline \multirow[t]{3}{*}{ BMI Pre-Test - Final test } & Negative sequences & $14^{b}$ & 7.50 & 105.00 & \multirow{3}{*}{$-3.30 * *$} & \multirow{3}{*}{.003} \\
\hline & Positive sequences & 0 & \multirow{2}{*}{.00} & \multirow{2}{*}{8.00} & & \\
\hline & Equal & 1 & & & & \\
\hline \multirow{3}{*}{$\begin{array}{l}\text { Fat percentage pre-test } \\
\text { - Final test }\end{array}$} & Negative sequences & $15^{\mathrm{b}}$ & \multirow{3}{*}{$\begin{array}{l}8.00 \\
.00\end{array}$} & \multirow{3}{*}{$\begin{array}{l}120.00 \\
.00\end{array}$} & \multirow{3}{*}{$-3.40 * *$} & \multirow{3}{*}{.001} \\
\hline & Positive sequences & 0 & & & & \\
\hline & Equal & 0 & & & & \\
\hline
\end{tabular}


the subjects. This research aligns with to our study and found significant results between pre-test and final test measurements.

In another research, Rogers and Gibson [19] has researched the effect of 8 week, 3 days a week, 60 minute Pilates mat exercise program on body composition, flexibility and muscular endurance for the healthy, recreationally active adults. The Pilates exercises consists of 7 start, 13 medium, 8 advance level exercises done with at most 10 repetitions. The cases in the control group in the research consisted of individuals who did uncontrolled cardiovascular and strength training for 60 minutes for 3 days a week in gym. The fat percentage of the cases in the Pilates group was found as $23.5 \pm 5$ on the average before the training and the fat percentage of the cases in the control group as $23.7 \pm 6$ on the average. The chest, waist, hip, right calf and arm girth measurements of the cases were measured by using Gullick tape, the chest, abdomen and thigh of men and triceps, suprailiac and thigh skinfold thickness of women by skinfold caliper. It was found out that the exercise program, also applied in our study, effects the anthropometric measurement results positively compared with pre-test results and this effect is statistically meaningful.

In the study done on 30 obese sedentary by Lafortuna et al. [20], a six week weight loss program was given to the individuals and statistically meaningful decrease in the body mass was found in the measurements made after six months ( $p>0.05$ ). This study also aligns with the result of our research.

\section{Conclusion}

In conclusion, the effects of regularly performed exercises, especially aerobic and resistance exercises done for women, on persons are seen in the literature and research essays. Deterioration in the body composition of women is seen depending on age and excessive weight.

\section{Conflict of interest}

The authors declare that there is no conflict of interests.

\section{References}

1. Şimşek D, Katırci H. Pilates egzersizlerinin postural stabilite and spor performans1 üzerine etkileri: sistematik bir literatür incelemesi [The effects of Pilates exercises on postural stability and sport performance: a systematical literature evaluation]. Physical Education and Sport Science Magazine, 20115; 2: 58-70. (In Turkish)

2. Janssen J, Fortier A, Husson R, Ross R. Effects of an energy-restrictive dietor with out exercise on abdominal fat, intermuscular fat, and metabolic risk factors in obese women. Diabetes Care, 2002;25:431-438. https://doi.org/10.2337/diacare.25.3.431

3. Stubbs RJ, Sepp A, Hughes DA, Johnstone AM, King N. et. al. The effect of graded levels of exercise on energy intake and balance in free-living women. International Journal of Obesity, 2002;26: 866-869. https://doi.org/10.1038/sj.ijo.0801874

4. Çolakoğlu FF. 8 Haftalık koş yürü egzersizinin sedanter orta yaşlı obez bayanlarda fizyolojik, motorik and somatotip değerleri üzerine etkisi [The effect of 8 week run-walk exercise on physiological, motoric and somatotype values for sedentary, medium aged obese women]. Gazi Üniversitesi Gazi Eğitim Fakültesi Dergisi, 2003; 23(3): 25-30. (In Turkish)

5. Çetin A. Geriatride Yaşam Kalitesi ve Rehabilitasyon [Quality of life and rehabilitation in geriatrics]. In: Gökçe Kutsal Y, ed. Geriatri. 2002. P. 218-221. (In Turkish)

6. Chu DA. Explosive Power and Strength: Complex Training for Maximum Results. Human Kinetics, Champaign; 1996.

7. Zorba E. Kadın ve Spor. [Women and Sports] [internet]. 2010. [cited 2019 Jan 22]. Available from: www.erdalzorba. com/5_Kadin-ve-Egzersiz.html (In Turkish)

8. Martin AD, Ward R. Body Composition, Measurement in Pediatric Exercise Science. First edition, Human Kinetics; 1996.

9. Ağaoğlu SA. Analysis of various physiological characteristics of physical education and sport department students at METU. [Master thesis]. Ankara: METU; 1989. (In Turkish)

10.Yabanc1 N. The effect of physical activity level and nutrition situation on the bone mineral intensity and body composition in adolescents. [Master thesis]. Ankara: Hacettepe
Üniversitesi; 1999. (In Turkish)

11.Zorba E. Fiziksel Uygunluk [Physical fitness]. $2^{\text {nd }}$ edition, Ankara: Gazi Kitapevi; 2001. (In Turkish)

12.Akın G, Tekdemir İ, Gültekin T, Erol E, Bektaş Y. Antropometri ve Spor [Anthropometry and Sports]. Ankara: Alter Yayıncilık; 2013. (In Turkish)

13.Koz M. Presentation called as: The relationship with body composition and sportive performance [internet]. 2012. [cited 2018 Nov 10]. Available from: http://80.251.40.59/ sports.ankara.edu.tr/koz/egz-fizII/vucut.kompz.egz.pdf (In Turkish)

14.Özer K. Fiziksel Uygunluk [Physical fitness]. $3^{\text {rd }}$ edition, Ankara: Nobel yayınları; 2010. (In Turkish)

15.Tamer K. Sporda Fiziksel-Fizyolojik Performansın Ölçülmesi ve Değerlendirilmesi [Measuring and assessing the physicalphysiological performance in sports]. Ankara: Bağırgan Yayınevi; 2000. (In Turkish)

16.Arslan E, Kelle M, Baylan Y, Diken H, Atmaca M, Tümer C, Obay B, Şermet A. Sporcularda plazma lipid düzeylerinin kendi aralarında ve kontrollerle karşııstașırılması [Comparison of plasma lipid level for athletes between themselves and controls]. Dicle Tip Dergisi [Journal of Medical School], 2001;28(1): 23-34. (In Turkish)

17.Cordero A, Masia MD, Galve E. Physical Exercise and Health. Revista Espanola de Cardiologia, 2014; 67(9): 748-753. https://doi.org/10.1016/j.recesp.2014.04.007

18.Erbas Ü. Orta Yas Obez Bayanlara Yönelik Kalistenik Egzersizlerin Fiziksel and Fizyolojik Etkileri [Physical and physiological effects of callisthenic exercises for middle aged, obese women]. Ankara; 2007. (In Turkish)

19.Rogers K, Gibson AL. Eight-Week Traditional Mat Pilates Training Program Effects on Adult Fitness Characteristics. Res Q Exerc Sport, 2009; 80(3): 569- 74. https://doi.org/10.1080/02701367.2009.10599595

20.Lafortuna CL, Resnik M, Galvani C. Effects of nonspecific vs individualized exercise training protocols on aerobic anaerobic and strength performance in severely obese subjects during a short term body mass reduction program. $J$ Endocrinal Invest, 2003;26:197-205. https://doi.org/10.1007/BF03345157 


\section{Information about the authors:}

Turgut M.; (Corresponding author); http://orcid.org/0000-0002-8556-3114; minetrgt@gmail.com; Faculty of Sport Sciences, Sakarya University of Applied Sciences; Esentepe Campus Serdivan Sakarya, 54050. Turkey.

Bağır S.; http://orcid.org/0000-0001-7663-7460; sbagirova@sakarya.edu.tr; Faculty of Sport Sciences, Sakarya University of Applied Sciences; Esentepe Campus Serdivan Sakarya, 54050. Turkey.

Sarıkaya M.; http://orcid.org/0000-0002-4062-0752; mücahit.sarikaya@hotmail.com; Physical Education and Sports High School, Van Yüzüncü Yıl University; Van, Turkey.

Tınaz Ü.; http://orcid.org/0000-0002-7960-0871; ummuhantinaz@hotmail.com; Physical Education and Sports High School; Bartın University; Bartın, 74100. Turkey.

\section{Cite this article as:}

Turğut M, Bağir S, Sarikaya M, Tinaz Ü. The effect of 8 week resistance exercise on some anthropometric measurements and body composition to Sedentary Women. Physical education of students, 2019;23(2):93-97.

https://doi.org/10.15561/20755279.2019.0207

The electronic version of this article is the complete one and can be found online at: https://sportedu.org.ua/index.php/PES/issue/archive

This is an Open Access article distributed under the terms of the Creative Commons Attribution License, which permits unrestricted use, distribution, and reproduction in any medium, provided the original work is properly cited http://creativecommons.org/licenses/by/4.0/deed.en

Received: 15.02.2019

Accepted: 18.03.2019; Published: 28.04.2019 